\title{
Principals' Management in Improving Professional Competence of Elementary School Teachers at Jaya Baru Sub-District, Banda Aceh
}

\author{
Marlina $^{1^{*}}$, Yusrizal ${ }^{2}$, Nasir Usman ${ }^{2}$ \\ ${ }^{1}$ Master of Educational Administration, Syiah Kuala University, Indonesia \\ ${ }^{2}$ Syiah Kuala University, Banda Aceh, Indonesia \\ *Corresponding email: syafrizalmarlina@gmail.com
}

Received: 09 March 2021

Accepted: 10 April 2021

Published: 11 August 2021

Abstract: This research used descriptive qualitative approach. Data collection were conducted through observations, interviews, and documentation. The subjects of this research are principal, vice principal, teacher, and supervisor. The results of this research shows: (1) The program was arranged at the beginning of school year by school development team, including dividing teachers task, arranging annual and semester program, planning to organize a workshop, participating in training, cultivating teachers, creating an innovative learning media, and supervising the class. (2) The program is always implemented according to predetermined plan. The implementation process shown by the improvement of teacher and student discipline, but the principal is still less assertive in disciplining the teacher; (3) The evaluation was done at the end of semester and become the follow-up to determine the following program. The result of evaluation was presented to teacher as individual or group; and (4) The obstacle that occurred are teacher have no basic skill in ICT, not mastering the teaching materials, lack of motivation to read.

Keywords: principals' management, professional competence, elementary school teacher.

Abstrak: Penelitian ini menggunakan pendekatan kualitatif deskriptif. Pengumpulan data dilakukan melalui observasi, wawancara, dan dokumentasi. Subyek penelitian ini adalah kepala sekolah, wakil kepala sekolah, guru, dan pengawas. Hasil penelitian menunjukkan: (1) Program disusun pada awal tahun ajaran oleh tim pengembangan sekolah, meliputi pembagian tugas guru, penyusunan program tahunan dan semester, perencanaan penyelenggaraan workshop, keikutsertaan pelatihan, pembinaan guru, pembuatan media pembelajaran yang inovatif, dan pengawasan kelas. (2) Program selalu dilaksanakan sesuai dengan rencana yang telah ditetapkan. Proses pelaksanaan ditunjukkan dengan peningkatan disiplin guru dan siswa, namun kepala sekolah masih kurang tegas dalam mendisiplinkan guru; (3) Evaluasi dilakukan pada akhir semester dan menjadi tindak lanjut untuk menentukan program selanjutnya. Hasil evaluasi dipresentasikan kepada guru secara individu atau kelompok; dan (4) Kendala yang terjadi adalah guru tidak memiliki keterampilan dasar TIK, tidak menguasai bahan ajar, kurangnya motivasi untuk membaca.

Kata kunci: menejemen kepala sekolah, kompetensi profesional, guru sekolah dasar.

\section{To cite this article:}

Marlina, Yusrizal \& Usman, N. (2021). Principals' Management in Improving Professional Competence of Elementary School Teachers at Jaya Baru Sub-District, Banda Aceh. Jurnal Pendidikan Progresif, 11(2), 400-410. doi: 10.23960/jpp.v11.i2.202120. 


\section{- INTRODUCTION}

Education is very necessary in order to develop self potential. Education is the most important thing in life so that every human being has the right to always develop in education. Education in general means a life process in developing each individual to live and live a life (Kairys, 2018; Anderson, Ellwood, \& Coleman, 2017; Dandan, \& Marques, 2017). This is stated in the Republic of Indonesia Law Number 20 of 2003 concerning the National Education System, "National education is a conscious and planned effort to create a learning atmosphere and learning process so that students actively develop their potential to have religious spiritual power, selfcontrol, personality, intelligence, noble character, and skills needed by him, society, nation and state. "So Education is a conscious and planned effort to create an active learning atmosphere.

The principal is a teacher who gets additional assignments and has advantages compared to his peers. The advantages possessed by the principal must guarantee the achievement of the goals and quality of education at school. The principal must play an active role in coordinating, mobilizing, and harmonizing the available educational resources. The role of the principal is crucial in implementing education quality management, especially in basic education institutions. "School principals will be easy to carry out their duties, if the school management they develop is able to influence, guide, coordinate and mobilize school resources in order to achieve goals.

Principal management is one of the factors that can encourage schools to be able to realize the vision, mission, goals and objectives of the school through programs that are implemented in a planned and enduring manner. This is consistent with the opinion of that: "Effective principals must at least know, be aware of, and understand three things: (1) why quality education is needed at school; (2) what must be done to improve the quality and production of schools; how to manage schools effectively to achieve high prestige (Bush, Bell, \& Middlewood, 2019; Chan, 2018; Cajiao, \& Burke, 2016).

Teacher professional competence is one of the competencies that must be possessed by every teacher in the education level. In concerning teachers and lecturers that the competencies that need to be possessed by a teacher include: pedagogic competencies, personality competencies, social competencies, and professional competencies obtained through professional education. Teacher professional competence, namely: (1) Mastery of teaching materials; (2) the ability to manage learning; and (3) knowledge about evaluation (Adams, Olsen, \& Ware, 2017; Kempa, Ulorlo, \& Wenno, 2017; Yieng, \& Daud, 2017).

One factor in the low quality of education in Indonesia is because of the weakness of teachers in exploring children's potential. Educators often impose their will without ever paying attention to the needs, interests and talents of their students. The quality of educators is also influenced by the culture applied in the school environment. Principal management is very influential to improve professional teachers, in carrying out their duties, principals must first know what competencies must be possessed so that they can easily direct all their subordinates to carry out the educational process in achieving educational goals.

\section{Study of literature \\ Understanding of education management}

In general, management can be understood as a science that can influence or empower organizational resources to achieve established goals effectively and efficiently. Management can also be defined as the ability or skill to obtain an outcome in order to achieve goals through the activities carried out (Ololube, Agbor, \& Agabi, 2017; Serdyukov, 2017). Management is also a process of integrating resources that are not 
connected to the entire system to achieve goals. Management can be applied in all activities, because it is universal and is a systematic knowledge framework. Management seeks to focus attention on the main administrative processes that include planning, organization, up to the evaluation process in order to achieve the expected goals and objectives.

As a process, management places its function on the interaction of people, both outside and inside the formal institution, or under or in someone's operational position in the organization. This illustrates that management has elements of cooperation and leads to the goals to be achieved. Management in practice is a set of activities that are interrelated and are a means to an end. "Management in a broad sense, is planning, implementation, and supervision (P3) of resources to achieve goals effectively and efficiently. While management in the narrow sense of school/madrasah management includes school and madrasah program planning, school / madrasah leadership, supervisor / evaluator, and school / madrasah information system (Bairaðauskienë, 2017; Böhlmark, Grönqvist, \& Vlachos, 2016).

\section{Educational management functions}

Sources of funds, resources, and human resources must be planned and used in such a way as to obtain the maximum possible benefits. Careful planning allows that to happen, because planning is the main function in implementing management. Management functions according to the planning function includes determining the objectives or framework of actions needed to achieve certain goals (Jamli \& Salim, 2019; Baharuddin, 2017; Wong \& Daud, 2017; Mohammed, Alotibie, \& Abdulaziz, 2016). Especially, in the learning process, planning is designed to facilitate the implementation of learning activities. Annual program planning and semester programs are arranged clearly to facilitate the implementation of learning. The management function is one of them planning. The forecasting process, practice, implementation and control that guarantees an activity is the meaning of planning. Planning is a conscious, organized and continuous effort to choose the best alternative from a number of alternatives in order to achieve the goal. Implementation activities are related to influencing people so that they like to carry out efforts towards achieving certain goals.

Organizing is defined as the whole process of grouping people, tools, tasks, responsibilities and authorities in such a way that they create an organization that can be mobilized as a whole in order to achieve its intended goals. Organizing functions namely function determination, relationships and structure. Functions are tasks that are divided into line functions, staff and functions. "organizing includes (a) dividing the components of activities needed to achieve goals into groups, (b) dividing tasks to someone manager to hold the grouping and (c) establish authority in between. There are three variations in the dependence of work units in an organization, namely as follows: Dependency is grouped, namely if organizational units are not dependent on one another, but are very dependent on adequate achievements, Dependence on scenarios is if an organization must carry out its activities first before the next unit acts. Mutual dependence involves reciprocal relationships between a number of organizational units, so that a common perception is obtained in referring to the organization

Supervision is the last action taken to manage an organization. "supervision is the process of observing or monitoring the implementation of organizational activities to ensure that all work being carried out is going according to a predetermined plan. Supervision can be formulated as a process of controlling and adjusting the path of the organization from the makeshift to the supposed or in other words 
supervision is intended to carry out an activity in accordance with the plan set before it. Through supervision it is expected that irregularities in various matters can be avoided so that goals can be achieved. Supervision is monitoring all activities to ensure the achievement of goals as planned at the beginning of the activity. Ensure that the policies and strategies that have been set are carried out in accordance with the spirit and spirit of the policy and strategy in question, the provision and use of work facilities in such a way that the organization obtains benefits as much as the size of the facility. Besides that the quality standards of work results can be fulfilled to the maximum extent possible and work procedures can be observed by all parties.

The institution's educational evaluation program is one of the functions of the education program management. In the learning process, it is an important factor in learning the level of success obtained from the process of activities that have been carried out. Through evaluation, various findings will be followed up in the implementation of future learning. Evaluation represents planned and systematic activities such: Evaluation or assessment is a series of activities carried out systematically, which includes the determination of objectives, planning and development of instruments, data collection, analysis, and interpretation to determine a value with predetermined assessment standards. The purpose of the evaluation is to answer whether there are significant differences between the desired results and the reality in the field (Zuilkowski, Piper, Ong'ele, \& Kiminza, 2018; Griffith et.al., 2017; Meyers \& Hambrick, 2017).

The purpose of evaluating various educational institutions. the objectives of the program evaluation are: Provide input for program planning, Provide input for continuation, expansion and termination of theprogram.Provide input to modify the program, Obtain information about program supporting and inhibiting factors., Provide input to motivate and guide the management and implementation of the program, Provide input to understand the scientific basis for program evaluation [9]. Based on the above description it can be concluded that the link between the planning function and program evaluation is a plan with program evaluation, or based on the results of identification of needs, and problems. The program implementation plan needs to be evaluated to find out the advantages, weaknesses, opportunities and challenges in achieving the goals.

\section{Professional Teacher Competencies}

The Government has formulated four types of teacher competencies, namely: The teacher competency standard is fully developed from four main competencies, namely pedagogical, personality, social, and professional competencies. The fourth competency integrated in teacher performance. With the issuance of concerning Standards for academic qualifications and teacher competence. This states that the teacher must have standards about these competencies. As well as is the ability of the Teacher to master knowledge in the fields of science, technology, and / or art and culture which he possesses which at least includes mastery: The subject matter is broad and in-depth in accordance with the standard content of the educational unit, subject, and / or subject group to be taught. Concepts and methods of relevant scientific, technological, or artistic disciplines, which are conceptually overshadowed or coherent with the education unit, subject matter, and / or group of subjects to be taught.

Professional Teacher Competence, Professional Competence is the ability that must be possessed by the teacher in the planning and implementation of the learning process. The teacher has a tuition to direct student learning 
activities to achieve learning goals, for which the teacher is required to be able to convey learning material. The teacher must always update, and master the subject matter presented. Preparation of material is sought by searching for information through various sources such as reading the latest books, accessing the internet, always keeping up with the latest developments and progress on the material presented. So that the presence of Teacher Professional Competence can be aimed at improving the cognitive and intellectual aspects of the students in order to maximize the realization of national education goals.

"Teachers as professional educators have an image that is good in the community if it can show the community that it deserves to be a role model or example or example of the surrounding community. The community will especially see how the teacher behaves or acts on a daily basis, whether there is someone who is exemplary or not. How a teacher can improve his services, improve his knowledge, give direction and encouragement to his students, and how teachers dress and talk after how to get along well with students, friends and community members, and teachers also often concern the public. As a professional teacher who is demanded by experts in various fields, a professional will always try to improve his professionalism with a variety of ways that can be pursued, can continue through higher education or through training.

\section{- METHODS}

The study used descriptive methods with a qualitative analysis approach. The choice of this method is based on consideration of data that provides an overview and illustrates a more complex social reality in such a way that it becomes a more concrete social phenomenon. The subjects in this study were principals, vice principals, teachers, and supervisors at the GgusJeruk School, Jaya Baru Sub-District,
Banda Aceh. Techniques for collecting data through observation, interviews, and documentation. Data analysis techniques with qualitative methods.

\section{- RESULTS AND DISCUSSION Principal program to improve teacher professional competence}

The results showed that the principal's program to improve teacher professional competence was arranged at the beginning of each school year together with teachers, staff, committees and parents of students and formed polling stations through deliberations in teacher council meetings involving all teachers and supervisors. The programs for enhancing teacher professional competence are planned as written in the RKAS, namely: holding workshops, including teacher coaching training in preparing lesson plans, arranging questions, by the school development team which includes annual programs and semester programs and not welldocumented and neat. The planned program is to provide guidance to teachers on a regular basis in the form of providing guidance on the preparation of learning activities, implementing learning, implementing KKG in schools and providing teaching aids or learning media, learning materials, learning media, creating questions about preparing evaluation instruments learning.

The program is a plan that involves various units containing policies and a range of activities that must be carried out within a certain period of time. Planning is a process or series of several interconnected activities in choosing one among several alternatives about the goals to be achieved by an organization or school. Then have strategies and methods to achieve these goals. It will also be followed by adjusting the budget to implement the strategy and method, accompanied by selecting and matching benchmark criteria to assess the level of organizational or school 
independence in achieving its objectives by implementing the strategy with the methods already selected.

Planning an academic supervision program by school supervisors and what the Principal does is starting with the creation of a supervisory program that includes annual programs and semester programs. Both programs were made at the beginning of the new school year. This aims to plan well what will be done. In addition to the supervisory program which includes annual programs and semester programs, academic supervision planning is also equipped with several supporting instruments. The supporting instruments are in the form of observation instruments, administrative documents for the learning process, observation instruments for observation of the implementation of learning plans and instruments for implementing classroom learning. This instrument is also very helpful for supervisors in carrying out most of their tasks listed in the annual program and semester program.

The presented several alternative teacher development programs, namely: "1) programs to improve teacher education qualifications, 2) equalization and certification programs, 3) integrated competency-based training programs, 4) education supervision programs , 5) KKG empowerment program, 6) teacher symposium, 7) other traditional training programs, 8) reading and writing journals or scientific work, 9) participating in scientific meetings, 10) conducting research, 11) internships, 12) following the actual news from news media, 13) active participation in professional organizations, 14) to collaborate with colleagues.

In the planning process, there are also several variations in planning responsibilities that depend on the size and purpose of the school and on the specific functions or activities of the principal. In general, schools need to consider the balance between long-term planning and short-term planning. It is very important for principals to understand the role of short-term and long-term planning in the overall planning pattern of showing that: In order for the planning of educational institutions both schools, madrasas, and Islamic boarding schools, as well as other organizations in accordance with realization that occurs in the field, then there is a good response by the principal / madrasah, and Islamic boarding schools as the person in charge of all and existing human resources institution with the aim of matching between the planning and the implementation that has been determined.

\section{Implementation of the principal's program to improve teacher professionalism}

Based on the results of the study it can be concluded that the implementation of management / programs to improve teacher professional competence begins with the assignment of duties and authorities in accordance with their respective abilities and duties and hold meetings to give grants by providing necessary information so that activities can be carried out properly. The motivation given by the principal in supporting the implementation of the school program is to provide rewards in the form of increasing the performance value for teachers who are wellperforming and given an assessment in the form of reducing the value stated in the teacher's SKP.

The principal also has the main task of managing the implementation of education and learning activities in schools. More operationally, the principal's principal duties include the activities of exploring and doubting all school resources in an integrated manner in the framework of designing school objectives effectively and efficiently. Principals must be able to organize staff and assist teachers in formulating programs for improving the quality of school learning by developing teachers' professional abilities, developing supervision, and stimulating teachers to actively participate in efforts to achieve goals. 
There are several legal bases that guide the principal to improve teacher professional competence, namely Law Number 20 of 2003 concerning the National Education System, Law No. 14 of 2005 concerning Teachers and Lecturers, Republic of Indonesia Government Regulation No. 16 of 2007 concerning Academic Qualification Standards and Teacher Competence, RI Minister of National Education Regulation Number 19 Year 2007 concerning Education Management Standards, Republic of Indonesia National Education Minister Regulation Number 23 Year 2006 concerning RI Competency Standards and Permendiknas Number 41 concerning Process Standards.

The principal as a vital element for the effectiveness of educational institutions determines the high and low quality of the institution, the principal is likened to an education commander who performs the function of controlling various patterns of teaching and education activities in it. Therefore, the success of a school depends on the extent to which the mission is imposed on its shoulders, its personality, and its ability to get along with the elements in it.

\section{Principal program evaluation in improving teacher professional competence}

The results of the study indicate that the implementation of the evaluation uses instruments or guidelines. However, there are some activities that do not yet provide evaluation guidelines and are based on the results of direct observation, such as guidelines for evaluating workshop implementation, guidelines for evaluating teachers in conducting classroom action research and guidelines for in house training activities. The results of the evaluation are neatly documented and are usually delivered to the teacher individually or in groups. The evaluation results serve as a follow-up in the form of procuring improvements if the implementation has not yet reached its maximum level as a follow-up program the following year.

Evaluation is a process of collecting, analyzing, and interpreting information in order to determine the extent of achieving goals by individuals. Educational evaluation is an assessment process in collecting and analyzing to determine the level of progress of an activity in education in order to establish achievement of goals both for education and students. Educational evaluation provides benefits for both students / education participants, and management. With the evaluation, students can find out the extent to which success has been achieved while attending education. In conditions where students get satisfactory scores, it will have an impact in the form of stimuli, motivators so that students can improve their achievements. In this condition where the results achieved are not satisfactory, students will try to improve learning activities, but it is very necessary to provide positive stimulus from the teacher. In terms of educators, the evaluation results can be used as feedback to determine efforts to improve the quality of education. Evaluation functions as: (1) Tools to determine the achievement of goals; (2) Process feedback is carried out; and (3) the basis for preparing progress reports.

The opinion of Priansa above shows that the evaluation activities are basically also intended to make improvements or improve business. Repairing a business without being preceded by an evaluation activity is not possible, because to make repairs in advance it must be known what needs to be improved. Evaluation activities that do not produce a starting point for improvement are empty and have no meaning at all.

Evaluation of the learning process emphasizes the assessment of the management of learning carried out by teachers including teacher performance in the classroom, effectiveness of learning media, class climate, 
attitudes and student learning motivators. Assessment of learning outcomes is an effort to take measurements of student learning outcomes, both using tests and non-tests, in this case is mastery of competence by each student in accordance with the characteristics of each subject. The results of the evaluation will allow evaluators to measure how far the progress or progress of the program is carried out in order to achieve the objectives that have been formulated. The principal as a manager must have capabilities related to procedures, methods, using tools, techniques, and processes needed by the organization.

The principal needs to think about and conduct an assessment that has been prepared or changed the way they are implemented. As the principal managerial competency regulated in one of them is "Monitoring, evaluating, and reporting on school activities / programs with the right procedures, and planning the follow-up". Based on the results of evaluating data, other methods are sought which are considered more appropriate and in accordance with the circumstances and needs. The course of changes have consequences in the form of re-registration. Thus it can be said that the evaluation has a function: support the preparation.

The constraints faced by principals in running school principals' management to improve teacher professional competence

The obstacles that occur in an effort to improve the professional competence of teachers are the lack of workshops and training, training is often carried out on the 2013 curriculum, the number of teacher teaching hours, the school principal's lack of discipline and regulations, the lack of motivation for teachers to add insight and reading books, journals and other references, both general fields and those relating to the material that will be taught to students, and there are still teachers who lack discipline in carrying out their duties.

The principal as a leader has a considerable contribution to the development and progress of the school. The development and progress of the school can be seen from the performance of professional principals and the principal is able to utilize existing resources effectively and efficiently. Looking at the diverse roles and duties of the principal, the principal is faced with the challenge of implementing a planned and sustainable education in developing the quality of education. This can be done by means of a school principal having a clear and directed vision. revealing the characteristics of effective principals include: Principals who are fair and decisive in making decisions, The principal divides the task fairly to the teacher, Principals who value staff participation, The principal who understands the teacher's feelings, Principals who have a vision and attempt to make changes, School principals who are skilled and disciplined, Principals who are capable and efficient, Principals who have dedication and are diligent, A sincere principal.

The opinion above shows that as a formal leader the principal is responsible for achieving the stated educational goals. In this case the principal is tasked with carrying out the functions of leadership, both functions related to the achievement of educational goals and the creation of a conducive school climate for the implementation of the teaching and learning process effectively and efficiently. The principal is a school person who is responsible for all school activities. The headmaster has full authority and responsibility for carrying out all educational activities in the environment that he implies.

\section{- CONCLUSIONS}

Based on the results of the study it can be concluded that: The principal's program is prepared after the beginning of the school year 
with the board of teachers, staff, committees, and parents of students from forming polling stations through deliberations in teacher council meetings involving all teachers and supervisors. The teacher professional competency enhancement programs planned as written in the RKAS are: holding workshops, including trainings, guiding teachers in preparing lesson plans, arranging questions, question cards, sola grids, preparing learning evaluation instruments, discussing TPK, doing class supervision and EDS activities.

The implementation of the program begins with the division of tasks and authorities in accordance with their respective abilities and duties and holds meetings to provide direction by providing necessary information so that activities can be carried out properly. The motivation given by the school principal in supporting the implementation of the school program in supporting the implementation of the school program is to provide rewards in the form of increasing the value of performance for good teachers and for those who lack performance in the performance score on the SKP.

Evaluation implementation uses evaluation instruments or guidelines. However, there are several activities for the unavailability of evaluation guidelines, such as guidelines for evaluating workshops, guidelines for evaluating teachers in conducting The results of the evaluation are documented and delivered to teachers both individually and in groups. The evaluation results are made as a follow-up in the form of making improvements if the implementation has not reached its maximum and becomes a follow-up program in the following year.

The obstacles that occur in efforts to improve teacher professional competence are the lack of workshop and training activities. The training that has been held so far is more about the 2013 curriculum, the many hours of teaching teachers and so many teacher administrations, it is less assertive that principals in carrying out discipline and regulations, still lack the motivation of teachers to add insight or read books, journals or other references, both general fields and with regard to the material that will be taught to students, and there are still teachers who lack discipline in carrying out their duties.

\section{Suggestion}

\section{Based on suggestions that can be submitted} based on the results of this study include:

Planning to improve teacher professional competence should be formulated to solve problems or carry out work in a school environment. Solving the problem is done by formulating the steps of the activity to find the best alternative in an effort to achieve school goals. These steps are basically those activities to determine various decisions about the activities to be carried out. By implementing these decisions, it is expected that school problems can be resolved or work can be carried out.

Implementation of teacher professional competencies must be properly implemented in an effort to improve teacher performance. This can use strategies, among others: following the teachers in upgrading to gain insight, giving teachers the opportunity to improve their skills and knowledge in teaching to a higher level, finding costs for teachers who continue their education through collaboration with the community, the world business or other cooperation that is not binding, guiding the teacher in matters relating to the planning and implementation of learning, the use of media learning and assessment of learning outcomes.

In conducting an evaluation of the professional competence of teachers, it should be carried out systematically and structurally involving the input, process and output. Learning evaluation emphasizes the assessment of the characteristics of students, the completeness and 
condition of learning facilities and infrastructure, the characteristics and readiness of teachers, curriculum and learning materials that are appropriate to the subjects, as well as the environment in which learning takes place.

The state of the school must have the right strategy to overcome obstacles by establishing harmonious relations with the environment, seeking new ideas, integrating each activity, setting an example for all education staff in schools, and providing media for innovative learning materials. The principal needs to continually improve the ways that have been done by increasing teacher competencies, especially professional competence

\section{REFERENCES}

Adams, C. M., Olsen, J. J., \& Ware, J. K. (2017). The school principal and student learning capacity. Educational Administration Quarterly, 53(4), 556-584. Anderson, L., Ellwood, P., \& Coleman, C. (2017). The impactful academic: Relational management education as an intervention for impact. British Journal of Management, 28(1), 14-28.

Baharuddin, M. (2017). THE INFLUENCE OF DIPLOMA BACKGROUND WORKING LIFEAND SITUATIONAL LEADERSHIP FACTOR OF HEADMASTER TOWARD THE PERFORMANCE OF HEAD OF STATE SCHOOL IN SAMARINDA. European Journal of Research and Reflection in Educational Sciences Vol, 5(4).

Bairaðauskienë, L. (2017). Headmaster's competencies in management area: evaluating the significance level of managerial competencies in Lithuanian comprehensive schools. European Journal of Multidisciplinary Studies, 2(5), 158164.
Böhlmark, A., Grönqvist, E., \& Vlachos, J. (2016). The headmaster ritual: The importance of management for school outcomes. The Scandinavian Journal of Economics, 118(4), 912-940.

Bush, T., Bell, L., \& Middlewood, D. (Eds.). (2019). Principles of Educational Leadership \& Management. SAGE Publications Limited.

Cajiao, J., \& Burke, M. J. (2016). How instructional methods influence skill development in management education. Academy of Management Learning \& Education, 15(3), 508-524.

Chan, M. L. (2018). Management education in the People's Republic of China. In Management Issues in China: Volume 1 (pp. 237-257). Routledge.

Dandan, M. M., \& Marques, A. P. (2017). Higher education leadership and gender gap in Jordan. Asian Development Policy Review, 5(3), 131-139.

Griffith, K. G., Jones, K., Howard, E., \& Winship, J. (2017). RURAL SCHOOL ADMINISTRATORS'PERCEPTIONS OF EDUCATORS'SKILLS NEEDED FOR EFFECTIVE INCLUSION CLASSROOMS. City Meets Country: Educators Working to Solve the Challenges of Special Education, 60, 52.

Jamli, N. F. A., \& Salim, S. S. S. (2019). Development of an Instrument to Evaluate Emotional Intelligence and Leadership Style of Headmasters across Primary Schools in Malaysia. INTERNATIONAL JOURNAL OF ACADEMIC RESEARCH IN BUSINESS AND SOCIAL SCIENCES, 9(7).

Kairys, M. R. (2018). The influence of gender on leadership in education management. International Journal of Educational Management.

Kempa, R., Ulorlo, M., \& Wenno, I. H. (2017). 
Effectiveness Leadership of Principal. International Journal of Evaluation and Research in Education, 6(4), 306-311.

Meyers, C. V., \& Hambrick Hitt, D. (2017). School turnaround principals: What does initial research literature suggest they are doing to be successful?. Journal of Education for Students Placed at Risk (JESPAR), 22(1), 38-56.

Mohammed, K., Alotibie, B. A., \& Abdulaziz, A. (2016). Total quality management in Saudi higher education. International Journal of Computer Applications, 135(4), 6-12.

Ololube, N. P., Agbor, C. N., \& Agabi, C. O. (2017). Effective leadership and management in universities through quality management models. In Innovation and Shifting Perspectives in Management Education (pp. 224-245). IGI Global.

Serdyukov, P. (2017). Innovation in education: what works, what doesn't, and what to do about it?. Journal of Research in Innovative Teaching \& Learning.

Wong, A. Y., \& Daud, K. (2017). Headmaster Technology Leadership in Malaysia Elementary Schools. Journal of Education and Learning, 11(2), 154-164.

Yieng, W.A., \& Daud, K. B. (2017). Technology leadership in Malaysia's high performance school. Journal of Education and eLearning Research, 4(1), 8-14.

Zuilkowski, S. S., Piper, B., Ong'ele, S., \& Kiminza, O. (2018). Parents, quality, and school choice: why parents in Nairobi choose low-cost private schools over public schools in Kenya's free primary education era. Oxford Review of Education, 44(2), 258-274. 